\title{
Identification of Five New Triterpenoids from Ethylacetate Bark Extract of Holoptelea integrifolia (Roxb.) Planch by GC-MS
}

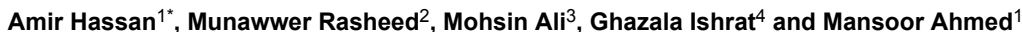

${ }^{1}$ Department of Pharmaceutical Chemistry, Faculty of Pharmacy, University of Karachi, Karachi, Pakistan

${ }^{2}$ Centre of Excellence in Marine Biology and Department of Chemistry, University of Karachi, Karachi, Pakistan

${ }^{3}$ Department of Chemistry, University of Karachi, Karachi, Pakistan

${ }^{4}$ Department of Pharmaceutics, Barrett Hadgson University, Karachi, Pakistan

*Corresponding author: Amir Hassan, Department of Pharmaceutical Chemistry, Faculty of Pharmacy, University of Karachi, Karachi, Pakistan, Tel: +92 3153632159 ; E-mail: ameerhassanhassan@yahoo.com

Received: August 14, 2018; Accepted: August 22, 2018; Published: August 29, 2018

Copyright: (c) 2018 Hassan A, et al. This is an open-access article distributed under the terms of the Creative Commons Attribution License, which permits unrestricted use, distribution, and reproduction in any medium, provided the original author and source are credited.

\begin{abstract}
n-hexane soluble ethylacetate extract (HIB-EA-HS) of bark of Holoptelea integrifolia (Roxb.) Planch was analyzed on GC-MS. The identified triterpinoids included: $\beta$-sitosterol (1), olean-13(18)-ene (2), betulin (3), $\alpha$-amyrenone (4), stigmasta-3, 5-diene-7-one (5), stigmast-4-en-3-one (6), friedelan-3-ol (7), and citrost-7-en-3-ol (8). Triterpenes (1), (3) and (7) have been reported previously but the other triterpenes (2), (4), (5), (7), and (8) were identified first time from the bark extract of $H$. integrifolia (Roxb.) Planch. Phytosteroids are an important class of natural products, and all these metabolites are quite known and common in higher plants. Important biological functions of the phytosterols induced LDL-cholesterol reducing potential and anti-colon cancer activity.
\end{abstract}

Keywords: Triterpienoids; H. integrifolia; GC-MS; Natural products; Metabolites

\section{Introduction}

Holoptelea integrifolia (Roxb) Planch (Ulmaceae) consists of 15 genera and 200 species. It is widely distributed in tropical temperate regions of the northern and Indian peninsula to Indo-China and Srilanka [1]. The common vernacular names of the plant in India are Chirabilva, Putigandha (Sanskrit), Papri (Urdu), Karanj, Putikaranj (Oriya) (Government of India) [2]. The plant $H$. integrifolia has been used traditionally for the treatment of inflammation, gastritis, dyspepsia, colic, intestinal worms, vomiting, wound healing, leprosy, diabetes, hemorrhoids, dysmenorrhoea and rheumatism [3]. Bark and leaves are used as bitter, astringent, thermogenic anti-inflammatory, digestive carminative, laxative, anthelminitic, depurative, repulsive, urinary astringent and in rheumatism [4]. In tribal area the juice squeezed out of mucilaginous boiled bark is used for rheumatic swelling [5].

Decoction of the bark used as oxytocic in pregnant ladies, paste of the stem bark is externally used to treat the inflammation of lymph glands, common fever and ring worm and seabies. Decoction of the leaves is used to regulate fat metabolism, treat eczema and coetaneous diseases [6].

Stem bark acts as an anti-inflammatory agent specifically for eyes. Bark and leaf paste of the plant are used externally on the white patches or leucoderma [7].

Bark paste is used for treatment of herpes simplex infection [8,9]. It is also reported for the treatment of intestinal cancer [10].

Bark and leaves of the plants are also used to treat cold, cough and weakness in cattle [11]. Seeds used topically on ring worm and dried fruit is used in polyurea and urinary disorders [12]. Various parts of the tree has been found to be useful in the treatment of bronchitis and obesity [13].

The ethanol crude extracts of stem bark of $H$. integrifolia was found anti-oxidant which is comparable to the standard vitamin E [14]. A number of 1,4-naphthalenedione (a phytochemical of the plant) derivatives have been found to have anti-bacterial activity [15].

Benzene, chloroform, methanol and aqueous extracts of stem bark of $H$. integrifolia showed anthelmintic activity against adult earth worm Pheretima posthuman [16].

The tree has been reported to contain various chemical constituents like terpenoids, saponins, tannins, proteins, carbohydrates, flavanoids and alkanoids [1].

The stem bark contains the triterpenoidal-fatty acid esters, holptelin-A (epi-friedelinol palmitate) and holoptelin-B (epifriedelinol stearate), friedelin and epi-friedelinol, 2aminonaphthaquinone and $\beta$-sitosterol, $\beta$-D-glucose were also isolated from stem bark [17].

Fractionation of crude methanol extract of the stem bark of $H$. integrifolia lead to the isolation of lupeol, ellagic acid and $\beta$-sitosterol$\mathrm{D}$-glucoside [18]. Lupane series compounds, betulinic acid and betulin, were also reported in the ethanolic extract of bark of $H$. integrifolia [19].

\section{Materials and Methods}

\section{Plant materials and chemicals}

The bark of the Holoptelea integrifolia plant was collected from the premises of the University of Karachi, Pakistan during January-April 2014 and identified by Prof. Dr. Ghazal Hafeez Rizwani Department of Pharmacognosy, University of Karachi. A herbarium voucher 
Citation: Hassan A, Rasheed M, Ali M, Ishrat G, Ahmed M (2018) Identification of Five New Triterpenoids from Ethylacetate Bark Extract of Holoptelea integrifolia (Roxb.) Planch by GC-MS. Nat Prod Chem Res 6: 338. doi:10.4172/2329-6836.1000338

Page 2 of 5

specimen No. 0045 was deposited in the museum of the Department of Pharmacognosy at University of Karachi, Pakistan [20]. The purified chemicals and all other reagents used during the research work were commercially purchased from Merck (Germany).

\section{Fractionation and isolation}

Holoptelea integrifolia plant bark $(10 \mathrm{~kg})$ were cleaned and then chopped into small pieces. These pieces were percolated in $80 \%$ methanol at room temperature for 15 days. The percolate was filtered thrice separately by using Whatman filter paper No.1. Thereafter, under reduced pressure and controlled temperature $40^{\circ} \mathrm{C}$, the filtrate was evaporated to dryness and the methanolic extract was lyophilized to a powdered form. Lyophilized powder $(300 \mathrm{~g})$ was partitioned with an equal quantity of distilled water $(450 \mathrm{ml})$ and ethylacetate $(450 \mathrm{ml})$ $1: 1$, ethylacetate layer was evaporated under reduced pressure and temperature $40^{\circ} \mathrm{C}$ to obtain ethylacetate extract [20]. The ethylacetate extract was triturated with warm $n$-hexane to obtain $n$-hexane soluble fraction (HIB-EA-HS).

\section{GC-MS for identification of the constituents}

n-hexane soluble fraction (HIB-EA-HS) was subjected to GC-MS to identify the compounds. For gas chromatography-mass spectrometric detection (GC-MS) a Hewlett Packed 5890 gas chromatograph was combined with a Jeol, JMS-600 mass spectrometer operating in EI mode with ion source at $250^{\circ} \mathrm{C}$ and electron energy at $70 \mathrm{eV}$ was used. Injector was set at $260^{\circ} \mathrm{C}$ with splitting ratio $1: 30$. Mass spectral survey was performed using MS libraries.

It is important to mention that the GC-MS and EIMS analyses were performed from an outsource laboratory (H.E.J Research Institute of Chemistry, University of Karachi, Karachi, Pakistan) (Tables 1 and 2).

\section{Results}

Triterpenes were obtained using GC-MS using n-hexane soluble fraction (HIB-EA-HS).

\begin{tabular}{|l|l|l|l|l|l|l|l|l|}
\hline Peak \# & Scan \# & R.T & M. Formula & M.Wt & Width & Area & Area Sum & Area Sum \% \\
\hline 22 & 10410 & 80.307 & $\mathrm{C}_{29} \mathrm{H}_{50} \mathrm{O}$ & 414 & 0.056 & 9174961 & 357689120 & 2.5650 \\
\hline 23 & 10427 & 80.44 & $\mathrm{C}_{30} \mathrm{H}_{50}$ & 410 & 0.065 & 7146787 & 357689120 & 1.9980 \\
\hline 24 & 10481 & 80.824 & $\mathrm{C}_{30} \mathrm{H}_{50} \mathrm{O}_{2}$ & 442 & 0.077 & 5157798 & 357689120 & 1.4419 \\
\hline 25 & 10521 & 81.128 & $\mathrm{C}_{30} \mathrm{H}_{48} \mathrm{O}$ & 424 & 0.077 & 21693201 & 357689120 & 6.0648 \\
\hline 26 & 10575 & 81.521 & $\mathrm{C}_{30} \mathrm{H}_{50} \mathrm{O}$ & 426 & 0.069 & 16576489 & 357689120 & 4.6343 \\
\hline 27 & 10606 & 81.744 & $\mathrm{C}_{29} \mathrm{H}_{46} \mathrm{O}$ & 410 & 0.06 & 4860629 & 357689120 & 1.3588 \\
\hline 28 & 10628 & 81.906 & $\mathrm{C}_{29} \mathrm{H}_{48} \mathrm{O}$ & 412 & 0.06 & 3049125 & 357689120 & 0.8524 \\
\hline 29 & 10699 & 82.421 & $\mathrm{C}_{29} \mathrm{H}_{48} \mathrm{O}$ & 412 & 0.075 & 20061002 & 357689120 & 5.6085 \\
\hline 30 & 10773 & 82.957 & $\mathrm{C}_{30} \mathrm{H}_{50}$ & 410 & 0.08 & 22764171 & 357689120 & 6.3642 \\
\hline 31 & 10832 & 83.404 & $\mathrm{C}_{30} \mathrm{H}_{52} \mathrm{O}$ & 428 & 0.083 & 51776991 & 357689120 & 14.4754 \\
\hline 32 & - & 83.889 & - & - & - & - & - & 3 \\
\hline 33 & 10953 & 84.277 & $\mathrm{C}_{32} \mathrm{H}_{54} \mathrm{O}_{4}$ & 502 & 0.086 & 3527380 & 357689120 & 0.9861 \\
\hline 34 & 11020 & 84.775 & $\mathrm{C}_{42} \mathrm{H}_{64} \mathrm{O}_{2}$ & 600 & 0.094 & 4083672 & 357689120 & 1.1416 \\
\hline 35 & 11129 & 85.577 & $\mathrm{C}_{30} \mathrm{H}_{52} \mathrm{O}$ & 428 & 0.111 & 18818976 & 357689120 & 5.2612 \\
\hline
\end{tabular}

Table 1: Data obtained by GC-MS of the fraction (HIB-EA-HS).

\begin{tabular}{|l|l|l|}
\hline Peak \# & Scan \# & Fragment ions m/z \\
\hline 22 & 10410 & $414(80), 396(53), 381(40), 367(5), 355(13), 329(45), 303(45), 255(42), 231(25), 213(45), 145(70), 107(75), 81(78), 55(100)$, \\
\hline 23 & 10427 & $\begin{array}{l}410(50), 395(30), 381(100), 355(10), 327(9), 303(8), 281(50), 269(25), 253(22), 218(75), 207(95), 161(35), 145(58), 121 \\
(60), 105(52), 95(75), 69(75), 55(98) .\end{array}$ \\
\hline 24 & 10481 & $\begin{array}{l}442(5), 411(10), 363(10), 337(4), 313(4), 288(6), 245(8), 234(25), 203(60), 189(100), 175(50), 147(45), 135(75), 95(80), 81(75), \\
69(55), 55(55) .\end{array}$ \\
\hline 25 & 10521 & $424(12), 355(2), 313(2), 281(20), 253(5), 231(8), 218(100), 203(25), 147(22), 135(25), 95(27), 81(27), 55(37)$. \\
\hline 26 & 10575 & $426(10), 297(2), 231(2), 218(100), 207(28), 147(20), 95(26), 55(26)$. \\
\hline
\end{tabular}




\begin{tabular}{|c|c|c|}
\hline 28 & 10628 & $\begin{array}{l}566 \text { (2), } 523 \text { (2), } 466 \text { (2), } 455 \text { (2), } 430 \text { (12), } 408 \text { (19), } 355 \text { (8), } 327 \text { (7), } 270 \text { (53), } 227 \text { (8), } 207 \text { (100), } 175 \text { (30), } 147 \text { (35), } 133(47), 105 \\
\text { (35), } 95 \text { (55), } 83 \text { (70), } 69 \text { (72), } 55 \text { (98). }\end{array}$ \\
\hline 29 & 10699 & 412 (30), 397(10), 370 (20), 355(12), 327 (12), 289 (21), 271(12), 229 (48), 187 (13), 147 (28), 124 (100), 95 (38), 69 (35), 55 (45). \\
\hline 30 & 10773 & $\begin{array}{l}566(2), 523(2), 503(2), 479(2), 430(2), 410 \text { (100), } 395 \text { (22), } 355(4), 327 \text { (4), } 297 \text { (4), } 269 \text { (45), } 256 \text { (7), } 227(12), 207 \text { (53), } 187 \\
(20), 174(50), 160(55), 147(50), 136(100), 107(55), 95(75), 81(70), 69 \text { (53), } 55 \text { (80). }\end{array}$ \\
\hline 31 & 10832 & 428 (10), 413 (15), 395(8), 275 (24), 231 (25), 207 (30), 165 (65), 135 (35), 109 (75), 95 (100), 69 (80), 55 (65). \\
\hline 32 & \multicolumn{2}{|c|}{ Not scanned } \\
\hline 33 & 10953 & $\begin{array}{l}523 \text { (2), } 479 \text { (2), } 426 \text { (5), } 383 \text { (10), } 355 \text { (10), } 313 \text { (10), } 281 \text { (48), } 253 \text { (20), } 229 \text { (8), } 207 \text { (100), } 191 \text { (20), } 133 \text { (30), 107(45), } 95 \text { (52), } 81 \\
(60), 55 \text { (98). }\end{array}$ \\
\hline 34 & 11020 & $\begin{array}{l}523(2), 504(2), 479 \text { (2), } 454(2), 426 \text { (5), } 406 \text { (22), } 394 \text { (10), } 355 \text { (10), } 327 \text { (8), } 281 \text { (48), } 254 \text { (28), } 227(5), 207 \text { (100), } 193 \text { (32), } 165 \\
(22), 147(23), 135 \text { (27), } 121 \text { (24), } 107 \text { (27), } 95 \text { (32), } 81 \text { (37), } 69 \text { (53), } 55 \text { (55). }\end{array}$ \\
\hline 35 & 11129 & $\begin{array}{l}428 \text { (80), } 398(20), 355 \text { (10), } 331 \text { (14), 287(30), } 281 \text { (28), } 245 \text { (54), } 231 \text { (25), } 207 \text { (75), } 191 \text { (25), } 161(23), 147(28), 137 \text { (68), } 107 \\
\text { (52), } 95 \text { (52), } 81 \text { (67), } 55 \text { (100). }\end{array}$ \\
\hline
\end{tabular}

Table 2: Data obtained by GC-EI-MS of the fraction (HIB-EA-HS).

\section{Discussion}

Triterpenes are rarely identified through GC-MS. These large molecules are usually non-volatiles and elute later from columns at elevated temperature. Therefore, if any, usually undergo thermal degradation some triterpenes or triterpenoids can survive thermal degradation and thus the current study has resulted in the identification of eight triterpenoids, thermally stable under the analytical conditions.

Isolation of $\beta$-sitosterol and friedelan-3-ol in earlier studies from bark of $H$. integrifolia [17] were found helpful in confirming the mass spectrum of peak \#22 (scan 10410) and peak \#31 (scan 10832) as $\beta$ sitosterol (1) and friedelan-3-ol (7) respectively. Betulin has been reported from the bark of the plant [19] therefore peak \#24 (scan 10481) was confirmed as betulin (3) from its previous GC-MS data and then also confirmed by comparing the data with electronic mass spectral library.

$\beta$-sitosterol (1) is known to possess anti-inflammatory and antipyretic [21], and antioxidant, and anti-diabetic potentials [22]. It has also been found to exhibit tyrosinase inhibitory [23] and radical scavenging properties [24]. It is a proven anticancer against certain cancers, human cancer cell lines (HL-60) [25]. Anticancer activity of compound (3) has been reported from the ethanolic extract of the bark of $H$. integrifolia [19].

The mass spectrum of peak \#23 (scan 10427) and peak \#25 (scan 10521) showed the molecular peak $[\mathrm{M}]^{+}$at $\mathrm{m} / \mathrm{z} 410,424$ respectively. Two characteristic ion peaks at $\mathrm{m} / \mathrm{z} 218$ and 207 were observed for peak \#23 (scan 10427) and for peak \#25 (scan 10521) at m/z 218 and 203. All these ion peaks resulted from retro-Diels-Alder cleavage of ring [26]. For peak \#23 (scan 10427) other fragment ions were also observed at $\mathrm{m} / \mathrm{z} \quad 410 \quad\left[\mathrm{M}-\mathrm{CH}_{3}\right]^{+}$and $395 \quad\left[\mathrm{M}-2 \mathrm{CH}_{3}\right]^{+}$. This fragmentation pattern when compared with electronic mass spectral library confirmed the presence of olean-13(18)-ene (2) and $\alpha$ amyrenone (4). Diol of olean-13(18)-ene (caflodiol) has been reported as anti-tumor, and its cytotoxic activity against human cancer cell lines [27]. Anti-Inflammatory and Antihypersensitivity effect of aamyrenone (4) has been documented [28].
For peak \#27 (scan 10606) strong intensity molecular peak $[\mathrm{M}]^{+}$was observed at $\mathrm{m} / \mathrm{z} 410$. Loss of side chain from C-17 gave characteristic fragment ion peak $[\mathrm{M}-141]^{+}$at $\mathrm{m} / \mathrm{z} 269$ but it was observed with one methyl group less at $\mathrm{m} / \mathrm{z} 253$. Two other very typical fragment ions of cholesta-3, 5-dien-7-one moiety were identified at $\mathrm{m} / \mathrm{z} 187$ and 174 (base peak). Both of these peaks arise due to the cleavage of ring $\mathrm{C}$ [29]. These findings upon comparison with electronic mass spectral library, were suggestive of the spectrum to be of stigmasta-3, 5diene-7-one (5). Compound (5) has been identified from the stem bark of $P$. angolensis by GC-MS analysis [30]. It has been reported as a free radical scavenge [31].

In case of peak \#29 (scan 10699) the mass spectral data showed molecular ion peak $[\mathrm{M}]^{+}$with $\mathrm{m} / \mathrm{z} 412$, with other peaks of fragment ions at $\mathrm{m} / \mathrm{z} 397,370,355,271,147$ and 124 . The molecular ion peak 412 represents the intact molecule and also gives the exact molecular weight of the compound. The $\mathrm{m} / \mathrm{z} 397$ is associated with the loss in mass of 15 from the molecular ion. This can be associated with the loss of methyl $\left(\mathrm{CH}_{3}\right)$ group $\left[\mathrm{M}-\mathrm{CH}_{3}\right]^{+}$. The $\mathrm{m} / \mathrm{z} 370$ arises from the loss in mass of 29. This is associated with the loss of ethyl group $\left(\mathrm{C}_{2} \mathrm{H}_{5}\right)$ from $\mathrm{m} / \mathrm{z}$ 397. The $\mathrm{m} / \mathrm{z} 355$ resulted from loss in mass of $15\left(\mathrm{CH}_{3}\right)$ from $\mathrm{m} / \mathrm{z}$ 370. The $\mathrm{m} / \mathrm{z} 271$ resulted from loss in mass of $141\left(\mathrm{C}_{10} \mathrm{H}_{21}\right)$ from the molecular ion. This gave vital information about the presence of a bulky side chain in the molecule. This is a characteristic of steroidal fragmentation pattern. The $\mathrm{m} / \mathrm{z} 147$ and 124 confirms the presence of rings and it resulted from the decomposition of $\mathrm{m} / \mathrm{z} 271$ [32]. This fragmentation pattern when compared with electronic mass spectral library confirmed the presence of stigmast-4-en-3-one (6). Compound (6) has been isolated as a constituent from the bark of Anacardium occidentale (Cashew) with its hypoglycaemic activity [33].

Peak \#35 (scan 11129) showed strong molecular ion peak $[\mathrm{M}]^{+}$at $\mathrm{m} / \mathrm{z} 428$. Other fragment ions were observed at $\mathrm{m} / \mathrm{z} 398\left[\mathrm{M}-2 \mathrm{CH}_{3}\right]^{+}$,

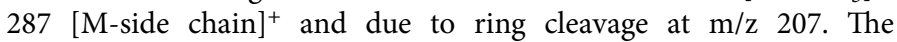
fragmentation pattern when compared with electronic mass spectral library confirmed the presence of citrost-7-en-3ol (8). It has been reported with its antioxidant property in the literature [34].

Identified and unidentified compounds (UI) were listed in Table 3 by following the same order of compounds as mentioned in result. 
Citation: Hassan A, Rasheed M, Ali M, Ishrat G, Ahmed M (2018) Identification of Five New Triterpenoids from Ethylacetate Bark Extract of Holoptelea integrifolia (Roxb.) Planch by GC-MS. Nat Prod Chem Res 6: 338. doi:10.4172/2329-6836.1000338

Page 4 of 5

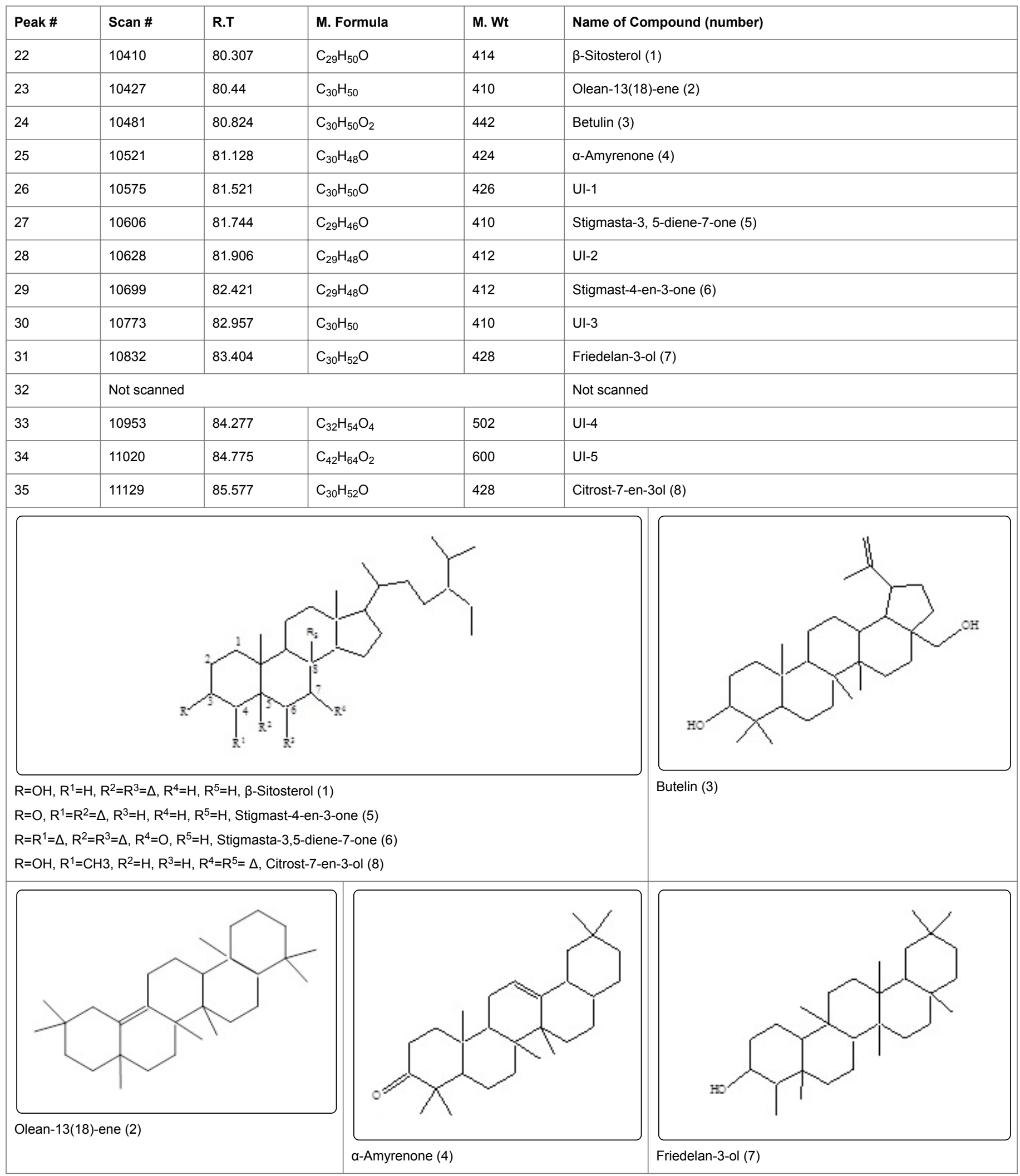

Table 3: Compounds identified through GC-MS. 
Citation: Hassan A, Rasheed M, Ali M, Ishrat G, Ahmed M (2018) Identification of Five New Triterpenoids from Ethylacetate Bark Extract of Holoptelea integrifolia (Roxb.) Planch by GC-MS. Nat Prod Chem Res 6: 338. doi:10.4172/2329-6836.1000338

Page 5 of 5

\section{Conclusion}

Identified triterpenoids (1-8) have also been identified and isolated from different plants but only one or two constituents were found in each species. In bark extract of Holoptelea integrifolia (Roxb.) Planch they all are gathered. Most of them have anticancer activity, and some have antioxidant, hypoglycemic, anti-inflammatory activity. Therefore, bark of $H$. integrifolia is rich with medicinal constituents and further study may lead to isolate an anticancer bioactive compound.

\section{References}

1. Mahmud S, Shareef H, Ahmad M, Gouhar S, Rizwani GH (2010) Pharmacognostic studies on fresh mature leaves of Holoptelea Integrifolia (Roxb.) Planch. Pakistan Journal of Botany 42: 3705-3708.

2. Mohafw H (1999) Government of India. Department of ISM and Ayurvedic. Pharmacopoeia of India, p: 39-40.

3. Warrier P, Nambiar V, Ramankutty C (1995) Indian Medicinal Plants: A Compendium of 500 Species. Orient Longman Pvt. Ltd, India 3: 162.

4. Prajapati N, Purohit S, Sharma A, Kumar T (2003) A Handbook of Medicinal Plant A complete source book. Agrobius (India), Jodhpur.

5. Nadkarni A (1976) Indian Material Medical Popular Prakashan Private Ltd., Bombay.

6. Kumar P, Rathna BJ, Kiladi S, Patrick C (2009) Preliminary Phytochemical and pharmacognostic Studies of Holoptelea integrifolia Roxb. Ethnobotanical Leaflets 10: 3.

7. Harsha V, Hebbar S, Shripathi V, Hegde G (2003) Ethnomedicobotany of Uttara Kannada District in Karnataka, India-plants in treatment of skin diseases. Journal of Ethnopharmacology 84: 37-40.

8. Parinitha M, Harish G, Vivek N, Mahesh T, Shivanna M (2004) Ethnobotanical wealth of Bhadra wild life sanctuary in Karnataka. Indian Journal of Traditional Knowledge 3: 37-50.

9. Mahishi P, Srinivasa B, Shivanna M (2005) Medicinal plant wealth of local communities in some villages in Shimoga District of Karnataka, India. Journal of Ethnopharmacology 98: 307-312.

10. Graham JG, Quinn M, Fabricant D, Farnsworth N (2000) Plants used against cancer-an extension of the work of Jonathan Hartwell. Journal of Ethnopharmacology 73: 347-377.

11. Rajakumar N, Shivanna M (2009) Ethno-medicinal application of plants in the eastern region of Shimoga district, Karnataka, India. Journal of Ethnopharmacology 126: 64-73.

12. Khare C (2007) Indian Medicinal Plants-An Illustrated Dictionary. 1st Indian Reprint Springer (India) Pvt. Ltd, New Delhi, India.

13. Rajbhandari M, Wegner U, Jülich M, Schoepke T, Mentel R (2001) Screening of Nepalese medicinal plants for antiviral activity. Journal of Ethnopharmacology 74: 251-255.

14. Saraswathy A, Devi SN, Ramasamy D (2008) Antioxidant, Heavy Metals and Elemental Analysis of Holoptelea integrifolia Planch. Indian Journal of Pharmaceutical Sciences 70: 13-16.

15. Vinod N, Shijina R, Dileep K, Sadasivan C (2010) Inhibition of betalactamase by 1, 4-naphthalenedione from the plant Holoptelea integrifolia. Applied Biochemistry and Biotechnology 160: 1752-1759.

16. Nadella D, Padmaa M (2010) Evaluation of anthelmintic activity of stem bark of Holoptelea integrifolia (Roxb) Planch. International Journal of Research in Ayurveda and Pharmacy (IJRAP) 1: 637-641.

17. Sharma P, Yelne M, Dennis T, Joshi A (2005) Database on Medicinal Plants Used in Ayurveda and Siddha. Central Council for Research in Ayurveda and Siddha, New Delhi, Government of India.
18. Durga N, Paarakh P (2012) Isolation of phytoconstituents from the stem bark of Holoptelea integrifolia (Roxb) Planch. Journal of Pharmacy Research 5: 532-533.

19. Ahmed M, Rizwani GH, Mohammed FV, Mahmood I, Ahmed VU, et al. (2013) Triterpenoid antioxidant agents found in Holoptelea integrifolia (Roxb) Planch. International Journal of Pharmaceutical Chemical and Biological Science 3: 63-67.

20. Guo H, Wang DS, Rizwani GH, Ahmed M, Hassan A, et al. (2013) Antineoplastic activity of Holoptelea integrifolia (Roxb.) Planch bark extracts (In vitro). Pak J Pharm Sci 26: 6.

21. Patil B, Rajput A (2012) GC-MS analysis of biologically active compounds of chloroform extract of leaves of Butea monosprrma. Journal of Pharmacy Research 5: 1228-1230.

22. Radika M, Viswanathan P, Anuradha C (2013) Nitric oxide mediates the insulin sensitizing effects of $\beta$-sitosterol in high fat diet-fed rats. Nitric Oxide 32: 43-53.

23. Muñoz E, Avila JG, Alarcón J, Kubo I, Werner E, et al. (2013) Tyrosinase inhibitors from Calceolaria integrifolia sl: Calceolaria talcana aerial parts. Journal of Agricultural and Food Chemistry 61: 4336-4343.

24. He R, Zou B, Fang H, Zhang Y, Wu Y (2013) Free Radical Scavenging Activities of b-Sitosterol Extracted from Abies yuanbaoshanensis. Asian Journal of Chemistry 25: 3507.

25. Nahata A, Saxena A, Suri N, Saxena AK, Dixit VK (2013) Sphaeranthus indicus induces Apoptosis through mitochondrial-dependent pathway in HL-60 cells and exerts cytotoxic potential on several human cancer cell lines. Integrative Cancer Therapies 12: 236-247.

26. Smith DL, Liu YM, Wood KV (1991) Structure elucidation of natural products by mass spectrometry. Modern Phytochemical Methods, pp: 251-269.

27. Ukiya M, Akihisa T, Tokuda H, Suzuki H, Mukainaka T, et al. (2002) Constituents of Compositae plants: III. Anti-tumor promoting effects and cytotoxic activity against human cancer cell lines of triterpene diols and triols from edible chrysanthemum flowers. Cancer Letters 177: 7-12.

28. Quintão NLM, Rocha LW, Silva GF, Reichert S, Claudino VD, et al. (2014) Contribution of $\alpha, \beta$-Amyrenone to the Anti-Inflammatory and Antihypersensitivity Effects of Aleurites moluccana (L.) Willd. BioMed Research International.

29. Baldé AM, Apers S, De Bruyne TE, Van Den Heuvel H, Claeys M, et al. (2000) Steroids from Harrisonia abyssinica. Planta Medica 66: 67-69.

30. Abubakar MN, Majinda RR (2016) GC-MS Analysis and Preliminary Antimicrobial Activity of Albizia adianthifolia (Schumach) and Pterocarpus angolensis (DC). Medicines 3: 3.

31. Delazar A, Nazifi E, Movafeghi A, Nazemiyeh H, Hemmati S, et al. (2010) Analyzes of phytosterols and free radical scavengers in the bulbs of Ornithogalum cuspidatum Bertol. Latin American and Caribbean Bulletin of Medicinal and Aromatic Plants 9: 2.

32. Kasal A, Budesinsky M, Griffiths WJ (2010) Spectroscopic methods of steroid analysis. Steroid Analysis, pp: 27-161.

33. Alexander Lindo RL, Morrison ESA, Nair MG (2004) Hypoglycaemic effect of stigmast-4-en-3-one and its corresponding alcohol from the bark of Anacardium occidentale (cashew). Phytotherapy Research 18: 403-407.

34. Selvaraj M, Mosses M (2016) Appraisal of important bioactive phytoconstituents in leaf and pod samples of citulrlus colocynthis (1.) Schard (family: cucurbitaceae) by application of GC-MS. 